\title{
Condition of Rumen Fermentation as Impacted by Supplementation of Fermented Rice Brand Using In Vitro Gas Production Technique
}

\author{
Zuratih $^{1 *}$, Budhi SPS ${ }^{2}$, Bachruddin $Z^{2}$ \\ IIndonesian Center for Animal Research and Development \\ ${ }^{2}$ Faculty of Animal Science, Univercity of Gadjah Mada \\ *E-mail: zuratih89@gmail.com
}

(received 13-11-2019; revised 30-03-2020; accepted 30-03-2020)

\begin{abstract}
ABSTRAK
Zuratih, Budhi SPS, Bachruddin Z. 2020. Kondisi fermentasi rumen dengan penambahan bekatul fermentasi dalam pakan secara in vitro. JITV 25(2):74-80. DOI: http://dx.doi.org/10.14334/jitv.v25i2.2066

Gas metana merupakan salah satu gas yang dihasilkan oleh ternak ruminansia dari fermentasi di dalam rumen. Adapun tujuan dari penelitian ini adalah untuk mengetahui produksi monakolin $\mathrm{K}$ pada fermentasi bekatul menggunakan kapang Monascus purpureus dan pengaruh suplementasi bekatul yang difermentasi dengan kapang Monascus purpureus pada pakan rumput gajah terhadap produk fermentasi dan produksi gas metana cairan rumen secara in vitro. Penelitian dilakukan dalam 2 tahap, yang pertama analisis kandungan monakolin $\mathrm{K}$ yang terkandung dalam bekatul yang difermentasi dengan kapang Monascus purpureus sebanyak 0, 4, 8, dan 12\% (v/w) dari substrat (bekatul). Analisis kandungan monakolin K pada substrat dilakukan dengan menggunakan HPLC. Penelitian tahap II yaitu analisis in vitro produksi gas dari 3 perlakuan pakan yaitu rumput gajah (kontrol), rumput gajah:bekatul (1:1), dan rumput gajah: bekatul fermentasi (kandungan monakolin $\mathrm{K}$ tertinggi (12\% dari substrat)) (1:1). Hasil penelitian tahap I menunjukkan bahwa fermentasi bekatul dengan dosis inokulum sebanyak $12 \%$ dari substrat memiliki kandungan monakolin $\mathrm{K}$ tertinggi $(1,39 \mu \mathrm{g} / \mathrm{ml})$. Hasil fermentasi in vitro pakan menunjukkan bahwa perlakuan pakan tidak berpengaruh $(\mathrm{P}>0,05)$ terhadap kandungan ammonia, VFA, $\mathrm{pH}$, aktivitas CMC-ase, protein mikroba, KCBK dan KCBO. Namun penambahan bekatul yang difermentasi pada pakan rumput gajah dapat menurunkan $(\mathrm{P}<0,05)$ produksi gas metana $\left(\mathrm{CH}_{4}\right)$ sebesar $50 \%$ dan populasi protozoa sebesar $80 \%$. Berdasarkan hasil tersebut dapat disimpulkan bahwa penambahan bekatul fermentasi yang mengandung monakolin $\mathrm{K}$ ke dalam pakan dapat menurunkan produksi gas metana secara in vitro tanpa mempengaruhi karakteristik fermentasi rumen.
\end{abstract}

Kata Kunci: Fermentasi, In Vitro, Metana, Monakolin K, Monascus purpureus

\begin{abstract}
Zuratih, Budhi SPS, Bachruddin Z. 2020. Condition of rumen fermentation as 1mpacted by supplementation of fermented rice brand using in vitro gas production technique. JITV 25(2):74-80. DOI: http://dx.doi.org/10.14334/jitv.v25i2.2066

Methane is one of the gases produced by ruminants during feed fermentation in the rumen. This experiment was aimed to investigate the production of monacolin $\mathrm{K}$ in rice bran fermented by Monascus purpureus mold and the influence of the supplementation of fermented rice bran using Monascus purpureus mold on elephant grass basal diet on fermentation products and methane production in an in vitro gas production method. The study consisted of two experiments. The first experiment analysis of monacolin K production in fermented rice bran using Monascus purpureus. Fermentation is done by the addition of Monascus purpureus at levels $0,4,8$, and $12 \%(\mathrm{v} / \mathrm{w})$ of substrate (rice bran) with 3 replications. Monacolin $\mathrm{K}$ in the substrate was analyzed using HPLC. The second experiment was the evaluation of supplementation of fermented rice bran to elephant grass basal diet using in vitro gas production. The treatment diet evaluated were Pennisetum purpureum (control), Pennisetum purpureum:rice bran (1:1 ratio), and Pennisetum purpureum:rice bran fermented. Each treatment was replicated 3 times. Results from the first experiment shows that rice bran with the highest monacolin $\mathrm{K}$ content was in rice bran fermented at $12 \%$ by Monascus purpureus. Result from the second experiment showed that supplementation of fermented rice bran to Pennisetum purpureum basal diet did not affect rumen ammonia concentration, VFA, protein microbial production, and dry matter and organic matter digestibility. However, methane production $\left(\mathrm{CH}_{4}\right)$ was reduced $(\mathrm{P}<0.05)$ by $50 \%$, and the protozoal population was decreased $(\mathrm{P}<0.05)$ by $80 \%$. It is concluded that supplementation of fermented rice brands containing monacolin $\mathrm{K}$ was able to reduce methane production and the protozoa population without affecting feed fermentation.
\end{abstract}

Key Words: Fermentation, In Vitro, Methane, Monacolin K, Monascus purpureus

\section{INTRODUCTION}

Global warming has been widely discussed in Indonesia and even in the world. Livestock is one of the contributors to greenhouse gas emissions (GHG). One source of GHG emissions from the livestock subsector is methane gas $(\mathrm{CH} 4)$ from the enteric fermentation and manure removed by ruminants. Beef cattle are the 
largest contributor to $\mathrm{CH} 4$ emissions (69.41\%) compared to other ruminants (Widiawati et al. 2016).

The efforts to reduce $\mathrm{CH} 4$ emissions from ruminants have been carried out in Indonesia, one of them is the use of secondary metabolites of plants such as essential oils, saponins, and tannins (Benchaar \& Greathead 2011; Bodas et al. 2012). However, the use of the compounds produced by bacteria and molds is still rarely done, such as the use of secondary metabolites from Monascus purpureus which has the potential to reduce about $30 \%$ methane production (Morgavi et al. 2013).

Monascus purpureus is one of the molds used in the production of food and medicine. Besides, this mold was known to produce the compounds of biologically active such as inhibitors 3-hydroxy-3-methyl-glutarylcoenzyme A reductase (HMGCR) (Shi \& Pan 2011). These compounds inhibit methanogenic growth in the rumen by in vitro (Beltowski et al. 2009).

Based on this fact, this research was aimed to determine the effect of monacolin $\mathrm{K}$ as a secondary metabolite of Monascus purpureus on methane gas production in rumen.

\section{MATERIALS AND METHODS}

Materials used were mold of Monascus from the Central Microbiology Inter-University Laboratory (PAU), rice bran, elephant grass, and rumen fluid of Filial Ongole Cattle (PO) owned by Faculty of Animal Husbandry, Gadjah Mada University.

This research was conduct in 2 phases. The first phase about the fermentation of rice bran with the addition of $0,4,8$, and $12 \%(\mathrm{v} / \mathrm{w})$ inoculum of Monascus from the total substrate (rice bran), and the second phase was the evaluation of the effect of using fermented rice bran as an additional feed on the base feed of elephant grass against methane production by In vitro gas test according to the Menke \& Steingass 1988 method.

\section{Fermentation of rice bran by Monascus purpureus}

A total of $50 \mathrm{~g}$ substrates was transferred to $250 \mathrm{ml}$ Erlenmeyer flasks, added distilled water (40\% DM) then autoclaved at $121^{\circ} \mathrm{C}$ for $30 \mathrm{~min}$, left it until the temperature becomes $25-30^{\circ} \mathrm{C}$. After that, the Monascus purpureus was inoculated into the substrate as much as $0,4,8$, and $12 \%(\mathrm{v} / \mathrm{w})$ from the dry weight of the substrate, then incubated for 9 days. Each level of inoculation was repeated 3 times. After the fermentation finished, weighed the product and dried in an oven at $100^{\circ} \mathrm{C}$ for 30 minutes to inactivate the mold, then continue baking at $50^{\circ} \mathrm{C}$ for 24 hours. After that, stir evenly, ground and samples were taken to measure the $\mathrm{pH}$ and levels of monacolin $\mathrm{K}$.

\section{PH measurement and analysis of monacolin K levels of fermented rice bran using HPLC}

$\mathrm{pH}$ measurement of the substrate was carried out by a digital $\mathrm{pH}$ meter. A total of 1-gram substrate was dissolved with $10 \mathrm{ml}$ of distilled water and then the $\mathrm{pH}$ was measured using a digital $\mathrm{pH}$ meter that had previously calibrated using a pH buffer of 4 and 7 . Measurement of monacolin $\mathrm{K}$ content was performed by using HPLC at the Toxicology and Pharmacology Laboratory of the Faculty of Pharmacy UGM. A total of $1 \mathrm{mg}$ the fermented product was milled and dissolved with $9 \mathrm{ml}$ of ethanol $67 \%(\mathrm{v} / \mathrm{v})$ then stirred at $50^{\circ} \mathrm{C}$ for 2 hours. After that, precipitated and then the supernatant was taken to be analyzed for monacolin $\mathrm{K}$ levels using HPLC according Zhang et al. 2013.

\section{In vitro gas production (Menke \& Steingass 1988)}

The feeds were tested using in vitro gas production from 3 treatments, namely elephant grass (control), elephant grass: rice bran (1:1), and elephant grass: fermented rice bran (1:1); each treatment consisted of 3 replications. The fermented rice brand used was the best result of the first phase, based on AOAC method (2006).

The fermentation medium was prepared by mixing $474 \mathrm{ml}$ of McDougall's buffer, $0.12 \mathrm{ml}$ of mineral B solution, $237 \mathrm{ml}$ of buffered solution, $237 \mathrm{ml}$ of mineral A solution, $1.22 \mathrm{ml}$ of resazurin solution and $49.5 \mathrm{ml}$ of reduced solution $\left(\mathrm{Na}_{2} \mathrm{~S}\right)$ put into the Erlenmeyer $2 \mathrm{~L}$. then mixed with $2,000 \mathrm{ml}$ of rumen fluid while continuously flushed with $\mathrm{CO}_{2}$ in anaerobic conditions before being put into a syringe glass. The ratio of rumen fluid and the medium is $1: 2(\mathrm{v} / \mathrm{v})$ (Karlsson et al. 2009).

Approximately $300 \mathrm{mg}$ of each test feed was put into the glass syringe which contains $30 \mathrm{ml}$ of fermentation medium. All glasses were then incubated in a modified water bath at $39 \mathrm{oC}$ for 72 hours then its gas production was observed. At $0,1,2,4,6,8,12,24$, 36,48 , and $72 \mathrm{~h}$ measurement volumes were recorded; samples of gases produced were taken in Vacutainer ${ }^{\circledR}$ tubes for $\mathrm{CH} 4$ concentration analysis using Gas Chromatography (GC) and then released. At the end of this incubation $(72 \mathrm{~h})$, the liquid phase was centrifuged at a rate of 3,000 g. Its filtrate was used for testing rumen fermentation parameters (ammonia levels, VFAs, $\mathrm{pH}$, and methane gas production) and microbial activity (CMCase, microbial proteins, and protozoal). The remaining material was filtered through sintered crucibles to determine in vitro apparent dry matter and 
organic matter degradability. The residual dry matter and organic matter contents were determined to refer to the AOAC (2006). Dry matter (DM) and ash contents were determined by drying at $105{ }^{\circ} \mathrm{C}$ for $8 \mathrm{~h}$ and at 550 ${ }^{0} \mathrm{C}$ for $6 \mathrm{~h}$, respectively.

Ammonia was determined according to Chaney \& Marbach (1962). A total of $0.5 \mathrm{~mL}$ filtrate was centrifuged at $10,000 \mathrm{~g}$ for 10 minutes, then $20 \mu \mathrm{L}$ of the sample supernatant was added with $2.5 \mathrm{~mL} \mathrm{LC} \mathrm{(a}$ mixture of phenol $50 \mathrm{mg} \mathrm{Na}$ nitroprusside and $10 \mathrm{gr}$ crustal phenol which dissolved with aquadest to $1 \mathrm{~L}$ volume) and $2.5 \mathrm{~mL} \mathrm{LD}$ (a mixture of hypochlorite and 5 gr NaOH, 21.31 gr $\mathrm{Na}_{2} \mathrm{HPO}_{4}$ anhydrous or 269.7125 gr $\mathrm{Na}_{2} \mathrm{HPO}_{4} 12 \mathrm{H}_{2} \mathrm{O}$ which dissolved with $100 \mathrm{~mL}$ aquadest and $25 \mathrm{~mL}$ sodium hypochlorite $5 \%$ ) then homogenized.

Measurement of VFA produced during in vitro fermentation was carried out according to Filípek \& Dvorrák (2009). A total of $0.2 \mathrm{~mL}$ of filtrate was added with $1 \mathrm{~mL}$ of metaphosphoric acid, then centrifuged at $10,000 \mathrm{~g}$ for 10 minutes. A total of $1 \mu \mathrm{L}$ of the supernatant sample was taken and injected into gas chromatography.

CMase activity was carried out using 0.1 acetate buffered solution; $1 \%$ CMC solution; cyanide carbonate solution; $\mathrm{Na}_{2} \mathrm{CO}_{3}$ solution; and $0.05 \%$ potassium ferricyanide solution (Halliwell \& Lovelady 1981).

Protozoal populations were taken from the incubation medium at the end of fermented $(72 \mathrm{~h})$. The population was counted in the counting chamber thick as $0.2 \mathrm{~mm}$ using a microscope with a magnification of 40 times (Diaz et al. 1993).

The determination of microbial protein levels was measured according to the Lowry method (Plummer 1987). A total of $0.5 \mathrm{~mL}$ sample was put into a test tube then added with $2.5 \mathrm{~mL}$ of Lowry B solution then homogenized and allowed to stand for 30 minutes. After that, it was added $0.25 \mathrm{~mL}$ of Lowry A solution and allowed to stand for 10 minutes at room temperature then read using a spectrophotometer at a $\lambda$ of $750 \mathrm{~nm}$.

The data obtained were statistically analyzed using a completely randomized directional pattern design using the SPSS Program version 16.0. If there are differences, the analysis continued with the Duncan Test.

\section{RESULTS AND DISCUSSION}

\section{Content of monacolin $\mathrm{K}$ of fermented rice bran}

The effect of Monascus purpureus level on $\mathrm{pH}$ and monacolin $\mathrm{K}$ production of rice bran is presented in Table 1. Table 1 shows that the inoculum dose of $M$. purpureus had a significant effect $(\mathrm{P}<0.05)$ on the $\mathrm{pH}$ and production of monacolin $\mathrm{K}$ substrate. The $\mathrm{pH}$ of the substrate with the addition of $12 \%$ inoculum was still within the normal range for the growth of M. purpureus is 7-8. This result was also supported by an increase of monacolin $\mathrm{K}$ levels. The highest production of monacolin $\mathrm{K}$ in this study was in the addition of $12 \%$ (v/v) inoculum that is $1.39 \mu \mathrm{g} / \mathrm{ml}$ or equivalent to 154 $\mathrm{mg} / \mathrm{kg}$. This result was lower than that reported by Morgavi et al. 2013 which produced $570 \mathrm{mg} / \mathrm{kg}$ monacolin $\mathrm{K}$ with fermented rice used as substrate and ammonium sulfate addition to increasing monacolin $\mathrm{K}$ production. This is caused by the carbohydrate content of rice bran is lower than rice, while the effectiveness of the fermentation of Monascus in producing monacolin is influenced by carbohydrate content (Liu et al. 2020). Besides, the addition of ammonium sulfate can also increase the content of monacolin K (Su et al. 2003).

\section{Characteristics of rumen fermentation}

The effect of fermented rice bran addition to elephant grass basal diet on rumen fermentation characteristics of $72 \mathrm{~h}$ in vitro incubations is presented in Table 2.

Table 2 shows that the addition of fermented rice bran using $M$. purpureus did not affect rumen ammonia levels. Ammonia levels in this study were 25 to 28 $\mathrm{mg} / 100 \mathrm{~mL}$, which was still in the normal range to support the growth of rumen microbes that is 10.21 to $35.76 \mathrm{mg} / 100 \mathrm{~mL}$ (Olijhoek et al. 2016). Ammonia levels in the rumen are indicative of protein degradation. Protein will be degraded to oligopeptides, then to peptides and amino acids, then the process of amino acid deamination will produce ammonia (Goldberg 2013). Besides, ammonia levels in the rumen also describe degradation and protein synthesis process by rumen microbes. If the feed is protein-deficient, the ammonia concentration in the rumen will be decreased, and the growth of rumen microbes will be slow, that causes decreased digestibility of feed (Suharti et al. 2019). As in this study, with the same ammonia levels in each treatment caused no difference in the digestibility of dry matter and organic matter (Table 4).

The addition of the fermented rice bran did not affect average VFA levels (acetate, propionate, and butyrate) and the acetate: propionate ratio. In this study, the proportion of acetate was higher than propionate. This caused the feed in the fermented liquid to contain a lot of fiber. Glucose-rich food increased propionate production while fiber-rich feed increased acetate production (Suryani et al. 2014). The addition of rice bran without or with fermentation using $M$. purpureus did not affect $(\mathrm{P}<0.05)$ on $\mathrm{pH}$ (Table 2$)$. The addition of fermented rice bran in this study resulted in a range of $\mathrm{pH}$ values that were still within the normal $\mathrm{pH}$ range for the rumen fermentation process, which is 6-7. These results were in line with that reported by Candyrine et al. (2018), that the addition of $2 \mathrm{mg} / \mathrm{kg}$ body weight/day lovastatin to goat feed resulted in rumen $\mathrm{pH}$ of 6.59 . 
Table 1. Average $\mathrm{pH}$ and monacolin $\mathrm{K}$ production of rice bran after fermentation with Monascus pupureus at various levels

\begin{tabular}{lcccc}
\hline \hline \multirow{2}{*}{ Parameters } & \multicolumn{4}{c}{ Monascus purpureus \% DM } \\
\cline { 2 - 5 } & 0 & 4 & 8 & 12 \\
\hline $\mathrm{pH}$ & $6.53^{\mathrm{a}} \pm 0.06$ & $8.50^{\mathrm{b}} \pm 0.30$ & $9.00^{\mathrm{c}} \pm 0.21$ & $8.20^{\mathrm{b}} \pm 0.06$ \\
$\mathrm{nonacolin} \mathrm{K}(\mu \mathrm{g} / \mathrm{ml})$ & $0.00^{\mathrm{a}} \pm 0.00$ & $0.01^{\mathrm{a}} \pm 0.01$ & $1.07^{\mathrm{b}} \pm 0.14$ & $1.39^{\mathrm{c}} \pm 0.21$ \\
\hline $\mathrm{a}, \mathrm{b}, \mathrm{c}$
\end{tabular}

Table 2. Ammonia levels, VFA, and pH of fermented rice bran with M. purpureus used as inoculum of 72 hours in vitro incubations

\begin{tabular}{lccc}
\hline \hline & \multicolumn{3}{c}{ Feed } \\
\cline { 2 - 4 } Parameters & Elephant grass & Elephant grass:rice bran $(1: 1)$ & Elephant grass:fermented rice bran $(1: 1)$ \\
\hline Ammonia $(\mathrm{mg} / 100 \mathrm{~mL})$ & $25.62 \pm 0.34$ & $28.05 \pm 1.60$ & $25.80 \pm 1.95$ \\
VFA (\%) & & & \\
Acetate & $78.00 \pm 1.83$ & $14.06 \pm 0.51$ & $76.39 \pm 0.84$ \\
Propionate & $15.77 \pm 0.53$ & $8.66 \pm 0.44$ & $15.99 \pm 1.48$ \\
Butyrate & $6.23 \pm 2.08$ & $5.40 \pm 0.18$ & $7.63 \pm 0.67$ \\
Acetate:propionate & $4.95 \pm 0.17$ & $6.26 \pm 0.08$ & $4.81 \pm 0.50$ \\
pH & $6.25 \pm 0.04$ & $5.53 \pm 1.29^{\mathrm{b}}$ & $6.30 \pm 0.07$ \\
Methane (mL/100 mg & $5.52 \pm 0.71^{\mathrm{b}}$ & & $2.75 \pm 1.14^{\mathrm{a}}$ \\
DM) & & & \\
\hline
\end{tabular}

${ }^{a, b}$ Means within rows and subtitles followed by distinct superscripts differ (Duncan Test at 5\%)

VFA: Volatile Fatty Acid

The addition of fermented rice bran reduced methane production $(\mathrm{P}<0.01)$ to $50.2 \% \quad$ (Table 2 ). These results were in line with that reported by Morgavi et al. (2013) that the use of rice bran fermented with Monascus sp. and hay with a ratio of 1: 1 in sheep reduced $30 \%$ methane production in vitro. This result caused by the Monascus sp. that produces secondary metabolites such as monacolin $\mathrm{K}$. Monacolin $\mathrm{K}$ is an HMG-CoA reductase inhibitor, which is an enzyme that plays a role in cholesterol formation (Sharpe \& Brown 2013a). With monacolin K, the formation of cholesterol will be disrupted so that the development of protozoal inside will also be disrupted because cholesterol is one of the constituent components of the protozoal cell membrane. Protozoal live in symbiosis with methanogenic bacteria (methane-producing bacteria) in the rumen. Methanogenic bacteria get a constant supply of hydrogen from protozoal, so a decrease in the protozoal population in the rumen will indirectly reduce methane production (Martin et al. 2010).

\section{Microbial activity}

Effect of fermented rice bran addition to elephant grass basal diet on rumen microbial activity of $72 \mathrm{~h}$ in vitro incubations is presented in Table 3.

\section{CMCase: Carboxymethyl cellulase}

Carboxymethyl cellulose is a cellulose degradation enzyme which is a polysaccharide contained in the feed (Sitoresmi et al. 2009). Results showed that the addition of rice bran without or with fermentation using $M$. purpureus did not affect the activity of CMCase fermentation fluid. Results were in line with that reported by Candyrine et al. (2018), the use of HMGCoA reductase inhibitors (mevastatin and lovastatin) did not affect the growth of a fiber-degrading bacteria in the rumen. 
Table 3. CMCase activity and the number of protozoal of fermented rice bran with M. purpureus used as inoculum of $72 \mathrm{~h}$ in vitro incubations

\begin{tabular}{lccc}
\hline \hline & \multicolumn{3}{c}{ Feed } \\
\cline { 2 - 3 } Parameters & Elephant grass & $\begin{array}{c}\text { Elephant grass:rice bran } \\
(1: 1)\end{array}$ & $\begin{array}{c}\text { Elephant grass:fermented rice } \\
\text { bran }(1: 1)\end{array}$ \\
\hline CMCase $(\mathrm{U} / \mathrm{g})$ & $1.98 \pm 0.67$ & $2.21 \pm 0.54$ & $2.23 \pm 0.15$ \\
Protozoal $\left(\mathrm{x} 10^{3}\right) / \mathrm{mL}$ & $24.39^{\mathrm{ab}} \pm 13.81$ & $30.67^{\mathrm{b}} \pm 6.29$ & $6.31^{\mathrm{a}} \pm 4.83$ \\
Microbial protein $(\mathrm{mg} / \mathrm{mL})$ & $0.20^{\mathrm{a}} \pm 0.06$ & $0.36^{\mathrm{b}} \pm 0.04$ & $0.18^{\mathrm{a}} \pm 0.63$ \\
\hline ab Means within rows and subtitles followed by distinct superscripts differ $($ Duncan test at 5\%)
\end{tabular}

${ }^{\mathrm{ab}}$ Means within rows and subtitles followed by distinct superscripts differ (Duncan test at 5\%)

Table 4. The digestibility of dry matter and organic matter of fermented rice bran with M. purpureus used as inoculum of $72 \mathrm{~h}$ in vitro incubations

\begin{tabular}{lccc}
\hline \hline & & Feed \\
\cline { 2 - 4 } Parameters & Elephant grass & $\begin{array}{c}\text { Elephant grass:rice } \\
\text { bran (1:1) }\end{array}$ & $\begin{array}{c}\text { Elephant grass:fermented rice } \\
\text { bran }(1: 1)\end{array}$ \\
\hline Dry matter digestibility & $41.63 \pm 8.53$ & $43.68 \pm 0.47$ & $44.46 \pm 8.79$ \\
Organic matter digestibility & $41.06 \pm 6.12$ & $41.63 \pm 1.96$ & $43.74 \pm 12.20$ \\
\hline
\end{tabular}

The addition of fermented rice bran using $M$. purpureus reduced the number of rumen fluid protozoal. As stated earlier, secondary metabolites (monacolin K) produced by $M$. purpureus are HMGCoA reductase inhibitors (Sharpe \& Brown 2013b). Monacolin K compounds competed with HMG-CoA reductase enzymes in binding HMG-CoA so that will be inhibited the formation of mevalonic acid, which is the stage of cholesterol formation. Cholesterol is one of the constituent components of the protozoal cell membrane so that with monacolin $\mathrm{K}$ the growth of protozoa in the rumen will also be disrupted, causing the protozoal population in the rumen to be reduced. In this study, the use of fermented rice bran reduced $74.13 \%$ the protozoa population. These results are in line with that reported by Dinesh et al. (2014), the addition of statin compounds (atorvastatin and simvastatin) can inhibit the growth of Leishmania donovani which is one type of protozoal.

The addition of fermented rice bran using $M$. purpureus did not affect the microbial protein. Microbial protein derived from bacteria, fungi, and protozoa in the rumen. The use of rice bran in the diet increased the population of protozoa and rumen microbes, which caused the addition of carbohydrates and fiber in the rice bran. As reported by Martínez et al. (2010), an increase in the ratio of carbohydrates in the feed will increase the protozoal population in the rumen. Whereas, the addition of fermented rice bran decreased the protozoal population due to the presence of Monacolin K. Therefore, the protozoal population decline causes a decrease in microbial protein production.
Effect of fermented rice bran on the digestibility of dry matter and organic matter

Effect of fermented rice bran addition to elephant grass basal diet on the digestibility of dry matter and organic matter of $72 \mathrm{~h}$ in vitro incubations are presented in Table 4.

The results show that the addition of rice bran without or without fermentation using $M$. purpureus did not affect $(\mathrm{P}>0.05)$ digestibility of dry matter and organic matter diet in vitro. These results are in line with that reported by Candyrine et al. (2018), the addition of fermented oil palm cake using Aspergillus terreus (lovastatin $850 \mathrm{mg} / \mathrm{kg} \mathrm{DM}$ ) on goat diet, did not affect the total rumen microbial population and feed digestibility. This result also indicated that there is not significantly different on the VFA, NH3 (Table 2), and rumen microbial protein (Table 3 )..

\section{CONCLUSION}

Fermentation of Monascus purpureus in rice bran produced Monacolin $\mathrm{K}$ with the best results at the level of $12 \% \mathrm{DM}$. The fermented rice bran reduced methane production by $50 \%$, protozoal population, and microbial proteins without affecting ammonia production, $\mathrm{pH}$, CMCase enzyme content, and nutrient rumen fluid in vitro. Monacolin $\mathrm{K}$ derived from $M$. purpureus has the potential to be used as an additive to animal feed for reducing methane production in the rumen. In vivo research needs to be done to see the benefits of using $M$. purpureus as a food additive in reducing emissions of enteric methane. 


\section{REFERENCES}

AOAC. 2006. Official Methods of Analysis. 18th Ed. Gaithersburg (MD): Association of Official Analytical Chemists.

Beltowski J, Wojcicka G, Jamroz-Wisniewska A. 2009. Adverse effects of statins-mechanisms and consequences. Curr Drug Saf. 4:209-228.

Benchaar C, Greathead H. 2011. Essential oils and opportunities to mitigate enteric methane emissions from ruminants. Anim Feed Sci Technol. 166-167:338355.

Bodas R, Prieto N, García-González R, Andrés S, Giráldez FJ, López S. 2012. Manipulation of rumen fermentation and methane production with plant secondary metabolites. Anim Feed Sci Technol. 176:78-93.

Candyrine SCL, Mahadzir MF, Garba S, Jahromi MF, Ebrahimi M, Goh YM, Samsudin AA, Sazili AQ, Chen WL, Ganesh S, et al. 2018. Effects of naturallyproduced lovastatin on feed digestibility, rumen fermentation, microbiota and methane emissions in goats over a 12-week treatment period. PLoS One. 13:1-19.

Chaney AL, Marbach EP. 1962. Modified reagents for determination of urea and ammonia. Clin Chem. 8:130 132.

Diaz A, Avendano M, Escobar A. 1993. Evaluation of Sapindus saponaria as a defaunating agent and its effects on different ruminal digestion parameters. Res Rural Dev. 5.

Dinesh N, Pallerla DSR, Kaur PK, Kishore Babu N, Singh S. 2014. Exploring Leishmania donovani 3-hydroxy-3methylglutaryl coenzyme A reductase (HMGR) as a potential drug target by biochemical, biophysical and inhibition studies. Microb Pathog. 66:14-23.

Filípek J, Dvořák R. 2009. Determination of the volatile fatty acid content in the rumen liquid: Comparison of gas chromatography and capillary isotachophoresis. Acta Vet Brno. 78:627-633.

Goldberg AL. 2013. Protein Degradation. In: Lennarz WJ, Lane MD. Encycl Biol Chem. 2nd Ed. Amsterdam (NL): Elsevier. p. 617-624.

Halliwell G, Lovelady J. 1981. Utilization of carboxymethylcellulose and enzyme synthesis by Trichoderma koningii. J Gen Microbiol. 126:211-217.

Karlsson L, Hetta M, Udén P, Martinsson K. 2009. New methodology for estimating rumen protein degradation using the in vitro gas production technique. Anim Feed Sci Technol. 153: 193-202.

Liu J, Luo Y, Guo T, Tang C, Chai X, Zhao W, Bai J, Lin Q. 2020. Cost-effective pigment production by Monascus purpureus using rice straw hydrolysate as substrate in submerged fermentation. J Biosci Bioeng. 129:229-236.
Martin C, Morgavi DP, Doreau M. 2010. Methane mitigation in ruminants: From microbe to the farm scale. Animal. 4:351-365.

Martínez ME, Ranilla MJ, Tejido ML, Saro C, Carro MD. 2010. Comparison of fermentation of diets of variable composition and microbial populations in the rumen of sheep and Rusitec fermenters. II. Protozoa population and diversity of bacterial communities. J Dairy Sci. 93:3699-3712.

Menke KH, Steingass H. 1988. Estimation of the energetic feed value obtained from chemical analysis and in vitro gas production using rumen fluid. Anim Bes Dev. 28:755 .

Morgavi DP, Martin C, Boudra H. 2013. Fungal secondary metabolites from Monascus spp. reduce rumen methane production in vitro and in vivo1. J Anim Sci. 91:848860.

Olijhoek DW, Hellwing ALF, Brask M, Weisbjerg MR, Højberg O, Larsen MK, Dijkstra J, Erlandsen EJ, Lund P. 2016. Effect of dietary nitrate level on enteric methane production, hydrogen emission, rumen fermentation, and nutrient digestibility in dairy cows. J Dairy Sci. 99:6191-6205.

Plummer DT. 1987. An Introduction to Practical Biochemistry. London (UK): McGraw-Hill Book.

Sharpe LJ, Brown AJ. 2013a. Controlling cholesterol synthesis beyond 3-hydroxy-3-methylglutaryl-CoA reductase (HMGCR). J Biol Chem. 288:18707-18715.

Sharpe LJ, Brown AJ. 2013b. Controlling Cholesterol Synthesis beyond 3-Hydroxy-3-methylglutaryl-CoA Reductase (HMGCR). J Biol Chem. 288:18707-18715.

Shi Y-C, Pan T-M. 2011. Beneficial effects of Monascus purpureus NTU 568-fermented products: a review. Appl Microbiol Biotechnol. 90:1207-1217.

Sitoresmi PD, Yusiati LM, Hartadi H, Peternakan F, Mada UG, No JF. 2009. Pengaruh penambahan minyak kelapa, minyak biji bunga matahari, dan minyak kelapa sawit terhadap penurunan produksi metan di dalam rumen secara. Bul Peternakan. 33:96-105.

Su YC, Wang JJ, Lin TT, Pan TM. 2003. Production of the secondary metabolites $\gamma$-aminobutyric acid and monacolin K by Monascus. J Ind Microbiol Biotechnol. $30: 41-46$

Suharti S, Aliyah DN, Suryahadi S. 2019. Karakteristik fermentasi rumen in vitro dengan penambahan sabun kalsium minyak nabati pada buffer yang berbeda. J Ilmu Nutr Teknol Pakan. 16: 56-64.

Suryani NIN, Mangku IK, Dan B, Ari IP. 2014. Fermentasi rumen dan sintesis protein mikroba kambing peranakan ettawa yang diberi pakan dengan komposisi hijauan beragam dan level konsentrat berbeda. Maj Ilm Peternak. 17:56-60. 
Widiawati Y, Rofiq MN, Tiesnamurti B. 2016. Methane emission factors for enteric fermentation in beef cattle using IPCC Tier-2 method in Indonesia. JITV. 21:101-111.
Zhang BB, Lu LP, Xia Y jun, Wang YL, Xu GR. 2013. Use of agar as carrier in solid-state fermentation for Monacolin $\mathrm{K}$ production by Monascus: A novel method for direct determination of biomass and accurate comparison with submerged fermentation. Biochem Eng J. 80:10-13. 